\title{
2. Knowledge production and its politicization within International Relations and Peace Studies
}

Burak Toygar Halistoprak

\section{INTRODUCTION}

This chapter focuses on how International Relations (IR) in general, and Peace Studies more specifically, have been engaging with questions regarding the politics of knowledge production. The chapter contextualizes Peace Studies mainly within the general field of IR and investigates the questions raised about knowledge production in these respective literatures. Debates on knowledge production in the discipline of IR are particularly relevant for, and in this chapter bridged to, the knowledge production literature in Peace Studies for three key reasons. Firstly, although Peace Studies has been an interdisciplinary field since its inception (Webel and Galtung, 2007), it is influenced heavily by debates within IR due to its (often normative) focus on questions of sovereignty and intervention. Peace Studies' interventionist stance has challenged the Realist and state/system-centric character of mainstream IR. This interaction has created an intense nexus between IR and the field of Peace Studies in which knowledge and theoretical debates in both fields have easily been exchanged and translated by each. Secondly, developments in international politics have had direct implications for the field of Peace Studies and its central concepts. Political developments such as decolonization, the end of the Cold War, and the interstate and civil wars of the 1990s have naturally influenced not only the literature but also the practice of peace. Thirdly, although the field of Peace Studies was initiated in the 1970s by Johan Galtung, the concept of peace has been central to the field of IR including its mainstream and more critical branches. Scholars of Peace Studies usually have a background in IR; or even if they do not they inevitably refer to the literature focusing on the concept of peace within the context of IR. Thus, this chapter explores the knowledge production debates first in IR and then it examines how they resonate in the field of Peace Studies. 
The subjective nature of knowledge in the academic field of IR and its subfields (such as Peace Studies, Security Studies, Foreign Policy Analysis) has long been disregarded. This was not just a disregard but also a deliberate choice by the dominant perspectives in the field which presented objectivity as the main prerequisite for the scientific merit of IR. For those scholars, the puzzle is not a complex one: IR is an academic field and as such provides answers to the reality that it aims to address. It follows from this that the main debate should focus on developing appropriate theories, methods and tools to understand the causal relations between variables and present understandable answers to the questions asked in the first place. Looked at in this way, the development of theories and the standardization of methodological processes are not different in their essence from the procedures followed in the natural sciences. Confirmed hypotheses will help to build and justify the main assumptions of a grand theory. Grand theories ought to be umbrella-like frameworks that are capable of explaining as many cases as possible through their assumptions and propositions under certain controlled conditions. In this sense, theoretical insights and their empirical testing precede practical application (Kaplan, 2005: 7). Once they survive scientifically systematized testing processes, theories are ready toolkits that can serve the ultimate aim of explaining the practical reality and also present handy tools for analysing the future trajectories of similarly formed social puzzles.

The questions regarding the subjective content of the abovementioned processes are either ignored or found irrelevant by the defenders of such epistemological stances because the researcher is considered to be capable of preserving objectivity during the conduct of scientific endeavour. In that sense, there is clearly a definable distance between the observer, the theoretical framework utilized and what is observed (Guzzini, 2013). In other words, theory and practical reality are two different categories that are separable from one another and the observer can use theory as an instrument to make sense of the practical reality. This stance, which relies on positivist philosophy of social science, had dominated the field for quite some time before being questioned by some scholars who problematized the way knowledge is generated in IR. According to these scholars, the overall process which is presented as a perfectly functioning scientific machinery was not and could not be exempted from questions posed by the political structure in which the process is taking place. In other words, the very assumption of the possibility of scientific objectivity was subjected to questioning, and subjectivity of the knowledge and its production processes provided the ground for critical scholars to engage with the politics of knowledge production.

Critical scholars' problematization relies on three main points of critique. Firstly, the epistemological stance that positions theory and practice at a distance from one another was criticized. In the social world, theory and practice 
are not always separable from each other (Jones, 1995, 2001). In fact, there is a constant interaction between theory and practice. Theory and practice in the social sphere are not mutually exclusive; instead they mutually and constantly construct each other. In other words, theory shapes the practice while practice opens the door to the reproduction of theory. This 'social' dimension in the field gained momentum especially in the 1980s and generated more synergetic approaches to the nexus between theory and practice. The 'Praxis' approach, which takes theory and practice to be in a constant social interaction, is based on such a synergetic approach (Jones, 1999: 154). Secondly, and related to the first point, objectivity of scientific research and of the researcher is not seen as guaranteed, nor even possible (Chan, 2010). The researcher is an integral part of the social world that is investigated and the research is conducted within this world which is shaped by political and social factors. The dualism between the social world on the one hand and the researcher on the other is found to be artificial, which challenges, if not extinguishes, the objectivity assumption. Thirdly, the formation of a research agenda, which is presented as a pure scientific endeavour in positivist philosophy of science, is also problematized by critical and poststructuralist branches of the discipline (Ashley, 1995). The critical accounts emphasized that the overall political context can be, and is, influential in the formation of research questions. For instance, the so-called 'timeliness' of a research agenda is a manifestation of its political relevance. Disregarding how overall political structure renders certain research agendas timely and sidelines others is a major fallacy, and it should be addressed as a problem.

Students of Peace Studies have also been engaged with the questions of knowledge generation in their specific field. It was initiated as a field with a strong normative agenda which intends to create a substantial social change in conflict-affected areas. ${ }^{1}$ For such a field, the conditions under which its knowledge is generated and transferred into policy-making are of utmost importance. Therefore, how this subfield positions itself with regard to the points of critique mentioned above is worth exploring. This chapter aims to explore these debates on knowledge production in IR and examines how they feed into the field of Peace Studies and vice versa. Following a general overview of how mainstream IR is challenged by critical scholars questioning the generation of knowledge in the field, the chapter unfolds into the specific subfield of Peace Studies and delves into the debates on the politics of knowledge production and the theory-practice nexus. 


\section{KNOWLEDGE PRODUCTION DEBATES IN INTERNATIONAL RELATIONS}

Debates about knowledge production are not new in the field of IR. The field has built a significantly thick literature on the subject as early as the 1950s and 1960s. What is referred to as the 'Second Great Debate' in the field is actually a reformation and reconstruction of the discipline in response to points raised on how IR epistemes should function (Kratochwil, 2006). However, the points of problematization regarding the generation of knowledge have diversified and deepened throughout the evolution of the discipline. The debate that took place within the context of the Second Great Debate mainly focused on methodological questions whereas the later conversation has been inspired by a Foucauldian gaze (Lewis, 2017) and helped to politicize the debate.

In its early period, the discipline of IR was shaped around studies of the political and diplomatic history of Europe. Inspired by political theories of classical writers such as Machiavelli and Hobbes, early IR scholars focused on presenting assumptions that can explain state behaviour in the international arena. The Classical Realist dominance in the discipline's early years relied on the assumption that states are the primary actors with an inherently self-help-focused and aggressive nature (Morgenthau, 1978). Knowledge-making claims about the anarchical structure of the international system were also consolidated through this early literature relying on entrenched assumptions suggested by the Classical Realist school. The uncertainty that is caused by international anarchy, according to this tradition, obliges states to act in a selfish manner and accumulate power to ensure their survival. These founding assumptions of the Realist tradition have been the 'standard knowledge' for IR expertise in the early years of the discipline. Any other accounts advocating the possibility of cooperation, collective security and world peace were labelled naïve and utopian (Carr, 2016). Considering the early seminal works on international politics written by authors like Morgenthau and Carr, it is fair to suggest that most of these studies were written in a tone addressing policy-makers or statesmen. They were defining how statesmen should act and informing their decision-making through supposedly standard knowledge regarding state behaviour as summarized above. In terms of the theory-practice relationship, it is also safe to suggest that it was a much more vivid relationship compared to the scientific/behaviouralist school which adapted a dualist understanding of theory and practice. Nevertheless, the early Realist tradition was utterly agnostic, if not negligent, regarding the 'how' questions of knowledge generation. Despite speaking directly to the practitioners and exhorting them on how they should act in decision-making, the early IR literature did not concern itself with questions regarding their own role in the consolidation of that standard 
knowledge. In other words, the assumptions theorized within early IR knowledge were taken as fixed, primordial and pre-given.

The Second Great Debate can be cited as the first endeavour to delve deeper into 'how' to produce knowledge within the field. The debate was initiated mainly by a group of scholars who defended a more 'scientific' approach to the field instead of historicist theorizing (Guzzini, 1998). This first engagement of the field with questions of knowledge generation was in fact through a debate that did not directly speak of knowledge generation. Rather, it was sparked by a methodological objection targeting the historicist understating ascendant in the early IR scholars' writings. The scientific school (later also called behaviouralist) emphasized that what is called IR theory had so far relied mainly on 'undisciplined speculation' on state behaviour and statesmanship (Kaplan, 1966: 19). What is proposed as universal and standard knowledge about the functioning of world politics had not been tested through systematically built scientific methods, according to the scientific school. Science, in that sense, must rely on empirical proof and this proof could only be obtained through scientific testing. IR, being a field of social sciences, is not exempt from this procedure to be able to produce and deliver scientific knowledge. As the pioneer of the scientific school, Kaplan states:

Modern science [...] insists upon the hypothetical character of all empirical knowledge. The test for communicable knowledge depends on replicability even if only in principle. Thus there is no distinction between the physical and human with respect to the need for confirmation and communication. (Kaplan, 1966: 4)

This empiricist understanding relies on a positivist philosophy of science that is built upon multiple dualisms between theory and practice, and the observer and the observed. As in the fields of natural sciences, the objectivity of the research and researcher is not just assumed possible but also presented as the major requirement for scientific knowledge production. At this point, it should be noted that the objection of the scientific school does not target the very assumptions of traditionalists regarding state, state behaviour and the nature of international politics. Rather, what is problematized by the behaviouralists is that traditionalists rely on pure philosophical argumentation without testing these arguments through scientific frameworks (Knorr and Rosenau, 1969). Another point to clarify is that although we can see the Second Great Debate as the first initiative to start a conversation in IR on knowledge production in retrospect, it should be understood that, when it was first initiated, this was an epistemological path-searching of a relatively young academic discipline. The parties of the debate did not engage with the issue of the politics of knowledge generation as such; instead, their stances were shaped in accordance with their 
opinions on the possibility of studying social issues through the methods consolidated in natural sciences.

The constructivist intervention to IR theory can be cited as a significant problematization of approaches which take knowledge as fixed and naturally objective. Constructivists pointed out the constructed nature of the social concepts positioned in the centre of the discipline's knowledge accumulation. Wendt's revisiting of the concept of anarchy and reframing it as socially constructed (Wendt, 1992) has introduced a social dimension into the discipline. The 'social' embedded in the major concepts of the discipline is subsequently discovered by this new generation of scholars. The main weakness of conventional IR was, according to this constructivist generation, to take social reality as self-existing and 'out there' waiting to be discovered by researchers. Yet, constructivists argue that knowledge is 'generated by the way we think or talk about it' (Collin, 1997: 2). Similarly, Weldes challenges the fixed notion of another major concept of IR, namely national interest, by emphasizing its elusive nature and how it is constructed through different discursive engagements with politics (Weldes, 1996). This approach to the generation of concepts and knowledge departs from the above-mentioned dualist understanding of knowledge. The assumed distance between theory and practice is no longer taken for granted; instead, theory and practice are considered to be in a social interaction through which knowledge is produced.

Although the constructivist take on knowledge generation revealed the 'social' dimension in IR, it was mainly more critical accounts, such as Neo-Gramscians, Poststructuralists, Postcolonial theory and the International Political Sociology school that engaged with knowledge production in a political manner. Conventional constructivists' exploration of subjectivity and social nature of the knowledge was not accompanied by a problematization that delves deeper into the politics of these social processes. Critical accounts mentioned above, on the other hand, problematized political dynamics that influence the processes in which knowledge is generated and distributed. Hence, critical scholars' questioning of knowledge production was not solely a methodological problematization but also aimed at a politically informed deconstruction. Robert Cox's famous separation between problem-solving theory and critical theory marks an important turning point in the IR literature in terms of its impacts on how knowledge is organized and categorized in the field. In Cox's terms theory, being 'always for someone and for some purpose' (Cox, 1996: 87), is not an objective tool for making sense of the practicality. Rather, it is framed as an instrument of either reproducing or challenging the prevailing order's founding dynamics. Cox defines theoretical perspectives that aim to correct the defective aspects of the prevailing order as problem-solving theories; while he defines perspectives that directly challenge the foundations of prevailing order and seek solutions outside of it as critical 
theories (Cox, 1981). It follows from this that the knowledge produced through problem-solving theories is in conformity with the prevailing order, while critical knowledge is normatively motivated for change. Based on this, knowledge production is political as much as it is an academic activity. Accordingly, discussing knowledge production becomes a debate less about the merits of certain methodological approaches and more a question of how the political context in which knowledge production takes place shapes the process itself.

The poststructural critique of conventional IR takes up this challenge of politicizing the engagement with knowledge production and emphasizes the nexus between power and knowledge. In poststructural critique, knowledge production is a social process that has a constitutive impact on the political reality (Adler-Nissen, 2012). Knowledge producers are not blessed with perfect objectivity; instead, producing knowledge is a relational activity (Brigg and Bleiker, 2010: 781). Moreover, it is a crucial element of the preservation of a certain status quo and it is thus necessary to break down the distinction between the subject and the object, the researcher and the research and knowledge producers and political practice. Ashley's deconstruction of Realist theory's participation in constructing sovereignty and anarchy as they have been practised within the context of the Cold War is a good example of poststructural problematization of knowledge production (1995). In Ashley's idiom, what is presented by conventional theories of IR as standard and fixed knowledge about the essence of international politics - and also practised in the international arena - was in fact an outcome of a knowledge production campaign relying on a relevantly tailored discursive construction. This campaign, according to Ashley, standardized a certain notion of sovereignty as the main ordering principle of international politics. This version of sovereignty relied on a strict dichotomy between the domestic and external, in which the former is characterized by the order provided through sovereignty, while the latter is represented as chaotic, and requiring action on a self-help basis. Hence, the conventional IR theories, according to the poststructural critique, participated in the construction of the knowledge that state actors of international politics should act on a self-help basis as the standard and rational pattern of state behaviour. In other words, knowledge produced within IR was not a pure analysis of what unfolds in international politics but was also an outcome and a constitutive element of it.

The Postcolonial school built its critique on similar grounds to poststructuralists but differed in its addition of a focus on agency. The Postcolonial school of IR mainly developed as deep critique of knowledge production processes which had allowed the Western experience to be presented as a universal experience/knowledge. Postcolonial scholars have problematized conventional IR and the knowledge produced through it, a knowledge which constructed a reading of history as if it were the product of a solely Western (mainly 
European) experience and disregarded the agency of the non-Western subalterns (Epstein, 2014). What is presented as universalist truth through the conventional IR discipline was defined as informed by the asymmetries between the West and the rest originating from the colonial experience (Grovogui, 2010). In this regard, the Postcolonial school does not take IR knowledge claims as full accounts of events, rather they are seen to be knowledge claims imposed upon the subaltern (ibid.: 241). Conventional IR, in this sense, was said to have developed a mode of knowledge production which is a product of the colonial discursive power of the West which designated 'reason (rationality), science (positivism), and sensibility (pragmatism)' as the three pillars of knowledge production (Grovogui, 2006: 27). The role of knowledge is therefore seen not simply as a mirror of reality, but also as 'a potent force for shaping what is "out there"' (Seth, 2011: 182). Thus, the knowledge produced through epistemologies that are negligent of colonial hierarchies are deliberate fallacies constructed to reproduce the colonial hierarchies.

Overall, it is fair to suggest that the early engagements with questions of knowledge production in IR were politically agnostic and more epistemological, whereas more recent challenges to mainstream IR problematize the issue politically and break down the problem into the construction of epistemological standards in the discipline. This overview of the way knowledge has been treated in different branches of IR is important as a context to the way in which the politics of knowledge has emerged as a subject in the subfield of IR that is Peace Studies. A look into the subfield of Peace Studies is also necessary to evaluate how these debates are translated into peace research.

\section{KNOWLEDGE PRODUCTION IN PEACE RESEARCH}

The subfield of Peace Studies was born and developed as an academic field in which practitioners and academics interact in a more constant and effective way compared to other fields of international studies. This is mainly because the field has had a strong normative agenda and has from the outset aimed to create substantial social change in conflict-prone and conflict-affected societies. Therefore, peace research has always been attuned to producing politically relevant and useful knowledge that serves the field's aim of creating social change (Bush and Duggan, 2014). This policy-oriented character of the field has been considered to be both an advantage and a shortcoming. On the one hand, as a value-oriented field, peace research had to always bear in mind policy-relevance and empirical realities when approaching research and producing outputs. That is why Galtung, the founding figure of the Peace Studies discipline, stated that peace research is in an inevitable relation with the domain of practice and it is this which grants an agential role to the researcher (Galtung, 1985). On the other hand, the field was criticized for being too 
focused on pragmatics and remaining largely cut off from theoretical debates (Paris, 2000: 28). The pragmatic focus of the field also brings with it the risk of getting into a vicious circle that is repetitive and reproductive of the prevailing order. This dilemma has further implications for the engagement of the field with questions of knowledge production.

Despite being developed as an interdisciplinary field, the subfield of Peace Studies has had direct connection points to the field of IR, since the enquiries about peace inevitably penetrate debates of intervention and sovereignty. Therefore, the literature on knowledge production in peace research has developed in parallel with the interrogations in the field of IR. Yet, it is also fair to suggest that scholars questioning knowledge production in peace research have never lacked a political dimension in their enquiry as was the case in the early debates in IR theory. Interpretivist and reflectivist critiques on knowledge production in the field of IR have been translated into the subfield of Peace Studies comprehensively. Nevertheless, the early peace research that was shaped within the context of the Cold War was also built upon the presupposition that theory and practice are clearly and categorically distinguished. Building on this dualist understanding, Rapoport (1970) distinguishes between 'pure' and 'applied' peace research. While the former refers to theoretical studies, the latter refers to policy-relevant research. Following the dualist understanding adapted by the scientific school of IR, Rapoport envisages theory and practice as two distinct categories at a distance to each other. In this regard, pure studies handle the concepts in a philosophical manner, and are not necessarily connected to the practical world. They fulfil 'expectations by making some proportion of the world better understood without necessarily bringing it under manipulative control' (Rapoport, 1970: 277). To engender and inform change is the business of applied research, which does not solely rely on the aim of understanding the world, but also changing it towards a desired direction. Therefore, Rapoport does not attribute an agential power to theoretical studies, 'pure research' in his terms, as it does not seek to generate and influence change.

What is neglected by this approach is the fact that the practice of peace relies on a certain understanding of peace constructed not only through practice but also through theory. For instance, studying sub-atomic particles is an example of pure research, whereas a study of its applications for developing nuclear energy is applied research. However, no such distinction is possible in the field of peace research. Discursive construction of peace through 'pure' research can and does shape the practice and the mode of peace sought in it. The rise of the 'social' dimension in the field generated ground for more synergetic approaches to the nexus between theory and practice. Building on the Frankfurt School of political theory, the 'praxis' approach suggests that theory and practice are mutually constitutive of each other (Jones, 1999: 154). Theory 
usually serves the aim of producing justifications for a certain social order into which it was born. The practical world constitutes the theory, while theory in return provides a reproductive social setting to this practical world. Once theory and practice are redefined in such a mutually constitutive manner, much wider avenues of deliberation for knowledge production become available.

The phrase 'knowledge production' itself signals a methodological departure from the positivist school, which assumes reality is out there waiting to be explored through scientific methods. If there is a production, the assumption of 'out there' reality is no longer relevant. Therefore, it is possible to suggest that scholars problematizing the knowledge production processes are distancing themselves from the positivist philosophy of science. The problematization of this production process also requires politicization of the enquiry as it departs from the assumption of objective reality. In that sense, the critical literature on knowledge production in peace research can be categorized into three main groups with reference to their points of problematization: (1) those delving into isolation of non-Western peace knowledge from mainstream literature; (2) those problematizing peace research for being reproductive of liberal interventionism; (3) those emphasizing the isolation of critical knowledge from policy-making.

The first point of critique mainly builds on the Postcolonial school's argument that the non-West is underrepresented, if not completely absent, in the mainstream literature, and this is a reflection of a knowledge production logic relying on colonial hierarchies between the West and non-West. The knowledge systems built within peace research, especially in the aftermath of the Cold War, have mostly built on Western ways of 'knowing' (Velthuizen, 2012) which refers to an epistemological setting, of which procedures standardized based on concepts and methods are produced as outcome of Western social, political and historical background. Despite the fact that peacebuilding theories' target cases are usually non-Western conflicts, the theoretical frameworks used to understand these conflicts and structures to be established in the post-conflict stage are an outcome of Western political experiences. Indigenous knowledge systems, which are defined as knowledge that is internally developed from the social processes inherent to the developing societies (Velthuizen, 2012), are utterly isolated from providing input to these theories and methodologies aiming to build sustainable peace in non-Western contexts. However, the relationship between knowledge production and sustainable peace is 'characterized by global interconnectedness, knowledge conversation and central value adding' (Velthuizen, 2012: 18). The exclusion of indigenous knowledge from the theory of peacebuilding has not only caused a fallacy in the theory and practice of peace but has also served as a tool for those who have power to maintain that power 'by their control of definitions and ways of transmitting socially valued knowledge' (Burns, 1981: 115). In that sense, 
the exclusion of non-Western knowledge from peace knowledge production is defined as a manifestation of violence through knowledge (ibid.: 116). Through the dominant knowledge production modes within peace research, the non-West, but especially Africa, has been presented as deprived of people or ideas and waiting to be saved. In addition, the inherently produced knowledge that steered and maintained those societies is shoehorned as 'non-science'. 'Indigenous knowledge systems (IKS) were not allowed into public domains, which were then exclusively reserved for knowledges, heritages, cultures, institutions, norms, and idiosyncracies of western society' (Odora Hoppers, 2002: 107). This is embedded, according to the critique, in the colonial rationality that peacebuilding relies on, in which 'internationals' lead the scene and 'locals' are subsumed or at worst even negated (Jabri, 2013: 3).

The second line of the critique emphasizes that peace research in general, and Peace Studies as a specific field, has been instrumental in the reproduction and preservation of a certain type of liberal peace and set it as the standard recipe to be practised. UN Secretary-General Boutros-Ghali's famous speech, 'An Agenda for Peace', set peace interventions as a new international norm, which evolved into comprehensive peacebuilding. He pointed out the need to build a new intervention framework that prioritizes human security over any other agendas, that aims first and foremost at relieving civilian suffering, and that is more proactive and multilateral. These new norms of practice were accompanied by a wide campaign of knowledge production varying from media coverage to building an academic literature (Lewis, 2017: 21). Peace Studies has also been subjected to the influence of this campaign. This is especially the case for the early literature on peace interventions that was shaped in the early aftermath of the Cold War and established based on two major assumptions: (1) that international peace is dependent upon the preservation and enlargement of the liberal international order; and (2) that conflict-prone societies can achieve change towards stability, development and peace through external intervention and by following the blueprints of Western liberal nation states.

Knowledge production within the field has been instrumental in setting liberal peace as the standard approach and reproducing it through problem-solving methodologies that remedy its defective features. In Richmond's terms, the field has produced knowledge through approaches that are characterized by 'methodological nationalism' and 'methodological liberalism' (Richmond, 2019). The former maintains that peace, security and order depend on the balance of power and a strict preservation of the international system that relies on the principle of non-intervention. It sees intervention as an exception and undermines the ethical basis of peacemaking. The field of Peace Studies serves as a means to institute the rules of conduct for situations in which this exceptional need emerges. In this mode of knowledge production 'the role of schol- 
arship was to design, refine and disguise intervention, if necessary' (ibid.: 4). The latter, on the other hand, addresses the failures of methodological nationalism that influenced the early period of the field. It promotes multilateralism and the UN system and operates through international financial institutions, regional organizations and transnational NGOs. Knowledge production within this context institutionalizes the principle of 'peace-as-governance', which can also be interpreted as a 'form of neoliberal governmentality' (ibid.: 5).

Methodological liberalism, in Richmond's terms, serves as a process of depoliticization of the overall post-conflict peacebuilding endeavour. Richmond's critique suggests that the field avoids politically informed knowledge production to seek guidelines for technical rationalities that can serve as handy tools for the liberal peace project. In this regard, the 'practical man' expects peace research to come up with efficient standard operating procedures for intervention frameworks (Richmond, 2019). Since theoretical debates inevitably provoke the politicization of action, this practical logic stands aloof to deep theory. "The "practical man" is suspicious of what he may regard as complex theory, is focused on means, assumes the political debate over ends is settled, and is unconcerned about everyday social or historical context' (Richmond, 2019: 10). The overall peacebuilding logic thus operates as a machinery that removes political questions and renders peace a question of technical expertise (Bächtold, 2015: 197). Following this argument, knowledge production processes are influenced by the promotion of this depoliticized version of peace and are criticized for reducing peacebuilding to bureaucratic means (Goetschel and Hagmann, 2009).

Thirdly, and related to the previous points, it is possible to suggest that the architecture of peacebuilding praxis does not facilitate access for counter-intuitive and critical knowledge to policy-making. As stated earlier, the field of Peace Studies aims to produce knowledge to influence change, and the question of how to contribute to this change towards a peaceful direction has been an inherent concern of the field. Yet, the fact remains that critical knowledge is either isolated from policy-making or distances itself deliberately from policy-relevancy (Paffenholz, 2014). Though they may criticize the depoliticization of peacebuilding discourse, many critical peace researchers have avoided policy-relevance in their studies. For some schools of thought, this was a deliberate choice and does not represent a weakness. Drawing on the praxis approach, the categories of theory and practice are not distinct for these scholars; instead, theory and practice interpenetrate one another and are mutually constitutive; therefore the knowledge that they produce suffices to fulfil the task of contributing to the desired change. In line with the poststructural and Foucauldian reflexes, critical peace researchers do not want to present alternative recipes and blueprints to the liberal peacebuilding project. For others, however, a lack of policy-relevance will only contribute to the 
fading away of peace research (Jutila et al., 2008: 625, as cited in Paffenholz, 2014: 43). It is still not an easy task to produce both critical and policy-relevant peace knowledge. 'To avoid being misused by power politics in providing alternatives to power holders that support their power systems, Critical Peace Research needs to face the challenge of being policy relevant in a responsible way' (Paffenholz, 2014: 45). Focusing on the 'everyday' and basing the praxis of peacebuilding on 'methodological everydayism' (Richmond, 2019) are offered as options that can bridge critical thinking and policy-relevance.

The synergies between peace researchers and donor institutions, which in most cases also act as practitioner organizations, sometimes limit access for counter-intuitive knowledge to policy-making. Contract-based research agendas and the responsibility of research teams to report to donors make it difficult to produce counter-intuitive knowledge or to inform policy-making (Bush and Duggan, 2014). A significant proliferation of organizations undertaking outsourced research undermines the critical and value-oriented heritage of the field. While the increase in the number of the agents producing peace knowledge helps to cultivate a culture of evidence-based policy-making in peacebuilding it also leads to the growth of a peace research industry, seeking to guarantee the flow of funding from donors to maintain its operation. Critique, or its radical versions, appears risky and detrimental for potential future 'business' that would be offered by practitioner donor institutions. In this context, critical peace researchers stick with established scientific approaches, adapt key standards of neutrality, objectivity, rigour and systematic approaches to assemble credibility and claim validity in the eyes of knowledge demanding practitioners (Aradau and Huysmans, 2019).

Overall, Peace Studies has been and continues to be exposed to questions regarding its knowledge production processes. The scholars of the field contribute to the field's reconsideration of its position vis-à-vis policy-making, the power-knowledge nexus and engagement with counter-intuitive knowledge outputs by increasingly delving deeper into knowledge production processes. Being a value-oriented field aiming to contribute to social change, it is not only a necessity but also an effective strategy to focus more on conditions shaping knowledge production for the field of Peace Studies.

\section{CONCLUDING REMARKS}

This chapter presented a general overview of knowledge production debates in IR and specifically in Peace Studies. Peace knowledge produced within IR and Peace Studies has passed through phases in which it was first taken as fixed; then methodologically challenged; politicized and finally deconstructed through problematization of the power-knowledge nexus. As knowledge production increasingly continues to be the subject of debate in the literature, four 
concluding remarks can be derived. Firstly, there is now a consensus that there is no single peace knowledge 'out there'. Instead, there are different conceptions, referent objects and agents of peace and their knowledge. Knowledge is relational. Therefore, the field needs to continue extending its focus into these relational positionalities in knowledge production. The fruitful debate over the conditions that influence knowledge production has the potential to contribute to the field's capacity to catalyse change.

Secondly, the debate should not be limited merely to methodological problematization. The substantial political questions prior to the standardization of methodologies should not be avoided by the scholars focusing on knowledge production in peace. In that sense, peace knowledge is not only a product of pure academic endeavour but is also the outcome of a broader context influenced by certain social, economic and political dynamics. Knowledge production debates, therefore, should also explore how academic processes interact with these dynamics. The nexus between political context and peace knowledge should not be reduced to a unidirectional influence of politics over knowledge. Instead, there is a need for exploration of how peace knowledge plays a constitutive role in the construction of politics as well.

Thirdly, it can be suggested that some points raised by the critiques of knowledge production also bring with them certain risks. Among others, the potential reification of local or indigenous knowledge comes to the fore. The isolation of non-Western local knowledge from the praxis of peace has been problematized within the literature (Odora Hoppers, 2002; Velthuizen, 2012). Nevertheless, local knowledge should not be considered to be a category independent of the politics of knowledge production. The problematization of hierarchical asymmetries between the West and non-West should not be equated to a glorification of local knowledge without questioning the conditions of the politics of knowledge in those contexts. Students of peace research should bear in mind that local knowledge relevant for peace praxis is also the outcome of political processes and can very well be reliant on the silencing of local subaltern subjects. Therefore, they should also be subjected to knowledge production enquires.

Last but not least, although this chapter mainly focuses on knowledge production within the academic sphere, it is also crucial to keep in mind that the production of peace knowledge is prolific, not limited to academic knowledge and spread into different aspects of social spheres varying from media coverage to the arts in peacebuilding processes. Therefore, focusing on specific peacebuilding endeavours such as transitional justice processes as this book does, and examining the politics of knowledge production within these endeavours, will deepen our understandings and help the amelioration of peace praxis more broadly. 


\section{NOTE}

1. See also Chapter 3 by Laurent Goetschel in this book.

\section{REFERENCES}

Adler-Nissen, R. (2012), Bourdieu in International Relations: Rethinking Key Concepts in $I R$, New York: Routledge.

Aradau, C. and J. Huysmans (2019), 'Assembling Credibility: Knowledge, Method and Critique in Times of "Post-Truth", Security Dialogue, 50 (1), 40-58.

Ashley, R. (1995), 'The Powers of Anarchy: Theory, Sovereignty, and the Domestication of Global Life (1988)', in J. Derian (ed.), International Theory: Critical Investigations, London: Palgrave Macmillan, pp. 94-128.

Bächtold, S. (2015), 'The Rise of an Anti-Politics Machinery: Peace, Civil Society and the Focus on Results in Myanmar', Third World Quarterly, 36 (10), 1968-83.

Brigg, M. and R. Bleiker (2010), 'Autoethnographic International Relations: Exploring the Self as a Source of Knowledge', Review of International Studies, 36 (3), 779-98.

Burns, R. (1981), 'Knowledge for Peace and Education', Bulletin of Peace Proposals, $12(2), 115-22$.

Bush, K. and C. Duggan (2014), 'How can Research Contribute to Peacebuilding?', Peacebuilding, 2 (3), 303-21.

Carr, E. H. (2016), The Twenty Years' Crisis, 1919-1939: Reissued with a New Preface from Michael Cox, London: Springer.

Chan, S. (2010), 'Accidental Scholarship and the Myth of Objectivity', in N. Inayatullah (ed.), Autobiographical International Relations, London: Routledge, pp. 27-32.

Collin, F. (1997), Social Reality, London and New York: Routledge.

Cox, R. W. (1981), 'Social Forces, States and World Orders: Beyond International Relations Theory', Millennium, 10 (2), 126-55.

Cox, R. W. (1996), Approaches to World Order, Cambridge: Cambridge University Press.

Epstein, C. (2014), 'The Postcolonial Perspective: An Introduction', International Theory, 6 (2), 294-311.

Galtung, J. (1985), 'Twenty-Five Years of Peace Research: Ten Challenges and Some Responses', Journal of Peace Research, 22 (2), 141-58.

Goetschel, L. and T. Hagmann (2009), 'Civilian Peacebuilding: Peace by Bureaucratic Means?', Conflict, Security \& Development, 9 (1), 55-73.

Grovogui, S. N. (2006), 'Encounters: Theory, Difference and Representations', in S. N. Grovogui (ed.), Beyond Eurocentrism and Anarchy: Memories of International Order and Institutions, New York: Palgrave Macmillan, pp. 25-64.

Grovogui, S. N. (2010), 'Postcolonialism', in T. Dunne et al. (eds), International Relations Theories: Discipline and Diversity, London: Oxford University Press, pp. 239-56.

Guzzini, S. (1998), Realism in International Relations and International Political Economy: The Continuing Story of a Death Foretold, London and New York: Routledge.

Guzzini, S. (2013), Power, Realism and Constructivism, New York: Routledge.

Jabri, V. (2013), 'Peacebuilding, the Local and the International: A Colonial or a Postcolonial Rationality?', Peacebuilding, 1 (1), 3-16. 
Jones, R. W. (1995), “Message in a Bottle?" Theory and Praxis in Critical Security Studies', Contemporary Security Policy, 16 (3), 299-319.

Jones, R. W. (1999), Security, Strategy and Critical Theory, Boulder, CO: Lynne Rienner Publishers.

Jones, R. W. (ed.) (2001), Critical Theory and World Politics, Boulder, CO: Lynne Rienner Publishers.

Jutila, M., S. Pehkonen and T. Väyrynen (2008), 'Resuscitating a Discipline: An Agenda for Critical Peace Research', Millennium: Journal of International Studies, 36 (3), 623-40.

Kaplan, M. A. (1966), 'The New Great Debate: Traditionalism vs. Science in International Relations', World Politics, 19 (1), 1-20.

Kaplan, M. A. (2005), System and Process in International Politics, Colchester: ECPR Press.

Knorr, K. and J. N. Rosenau (1969), 'Tradition and Science in the Study of International Politics', in Contending Approaches to International Politics, Princeton, NJ: Princeton University Press, pp. 3-19.

Kratochwil, F. (2006), 'History, Action and Identity: Revisiting the "Second" Great Debate and Assessing its Importance for Social Theory', European Journal of International Relations, 12 (1), 5-29.

Lewis, D. (2017), 'The Myopic Foucauldian Gaze: Discourse, Knowledge and the Authoritarian Peace', Journal of Intervention and Statebuilding, 11 (1), 21-41.

Morgenthau, H. J. (1978), Politics among Nations: The Struggle for Power and Peace, New York: Alfred A. Knopf Inc.

Odora Hoppers, C. A. (2002), 'Indigenous Knowledge Systems, Sustainable Livelihoods and the Intellectual Property System: A Peace Action Perspective', Journal of Peacebuilding \& Development, 1 (1), 106-12.

Paffenholz, T. (2014), 'Critical Peace Research and Policy', in L. Goetschel and S. Pfluger (eds), Challenges of Peace Research-7, Bern: swisspeace, pp. 43-8.

Paris, R. (2000), 'Broadening the Study of Peace Operations', International Studies Review, 2 (3), 27-44.

Rapoport, A. (1970), 'Can Peace Research Be Applied?' The Journal of Conflict Resolution, 14 (2), 277-86.

Richmond, O. P. (2019), 'Interventionary Order and its Methodologies: The Relationship between Peace and Intervention', Third World Quarterly, 41 (2), 1-21.

Seth, S. (2011), 'Postcolonial Theory and the Critique of International Relations', Millenium Journal of International Studies, 40 (1), 167-83.

Velthuizen, A. (2012), 'Community Sites of Knowledge: Knowledge Creation and Application for Sustainable Peace in Africa', African Sociological Review/Revue Africaine de Sociologie, 16 (2), 2-21.

Webel, C. and J. Galtung (eds) (2007), Handbook of Peace and Conflict Studies, London: Routledge.

Weldes, J. (1996), 'Constructing National Interests', European Journal of International Relations, 2 (3), 275-318.

Wendt, A. (1992), 'Anarchy is What States Make of it: The Social Construction of Power Politics', International Organization, 46 (2), 391-425. 